\title{
The prognosis of critically ill patients with invasive group A streptococcus infection
}

Toshihide Izumida ${ }^{1}$ (D) and Teruhiko Imamura ${ }^{2^{*}}$

Keywords: Cardiology, Critical care medicine, Sepsis

To the Editor:

We read with great interest the article of Björck et al., demonstrating that critically ill patients with invasive group A streptococcus (iGAS) infection had a lower mortality risk compared to critically ill sepsis patients with other microorganisms. Furthermore, GAS classified with $e m m 1 / \mathrm{T} 1$ was associated with lower mortality than GAS with non-emm1/T1 [1]. We have two concerns that should improve their findings.

The first concern is whether iGAS infection per se is associated with a lower risk of mortality compared with other microorganism infections. There might be several confounding factors in their cohort. The control group included many patients with hospitalacquired infections and commodities, such as malignancy and immunosuppression. The authors might need to adjust for these factors or exclude the patients with hospital-acquired infection to evaluate the impact of iGAS per se.

The second concern is the management of critically ill patients with iGAS infection. The mortality and morbidity of patients with iGAS in their cohort were lower than previously reported cohort [2]. Although GAS with $e m m 1 / \mathrm{T} 1$ is a leading cause for necrotizing soft-tissue infection, the early diagnosis and prompt aggressive treatment for necrotizing fasciitis are the only way to improve mortality $[3,4]$. The authors might need to describe their detailed management, including data of the time from presentation to the first debridement, to evaluate the effect of therapy on the mortality and morbidity of iGAS in the real-world setting.

\section{Acknowledgements}

Not applicable.

\section{Authors' contributions}

All authors contributed to the drafting of the manuscript. All authors read and approved the final manuscript.

\section{Funding}

No.

\section{Availability of data and materials} Not applicable.

\section{Ethics approval and consent to participate}

Not applicable.

\section{Consent for publication}

Not applicable.

\section{Competing interests}

The authors declare that they have no competing interests.

\section{Author details}

${ }^{1}$ Division of Community Medicine, Kanazawa Medical University Himi Municipal Hospital, 1130 Kurakawa, Himi, Toyama, Japan. ${ }^{2}$ Second Department of Medicine, University of Toyama, 2630 Sugitani, Toyama 930-0194, Japan.

* Correspondence: teimamu@med.u-toyama.ac.jp

${ }^{2}$ Second Department of Medicine, University of Toyama, 2630 Sugitani,

Toyama 930-0194, Japan

Full list of author information is available at the end of the article

(c) The Author(s). 2020 Open Access This article is licensed under a Creative Commons Attribution 4.0 International License, which permits use, sharing, adaptation, distribution and reproduction in any medium or format, as long as you give appropriate credit to the original author(s) and the source, provide a link to the Creative Commons licence, and indicate if changes were made. The images or other third party material in this article are included in the article's Creative Commons licence, unless indicated otherwise in a credit line to the material. If material is not included in the article's Creative Commons licence and your intended use is not permitted by statutory regulation or exceeds the permitted use, you will need to obtain permission directly from the copyright holder. To view a copy of this licence, visit http://creativecommons.org/licenses/by/4.0/ The Creative Commons Public Domain Dedication waiver (http://creativecommons.org/publicdomain/zero/1.0/) applies to the data made available in this article, unless otherwise stated in a credit line to the data. 
Received: 15 June 2020 Accepted: 9 July 2020

Published online: 14 July 2020

\section{References}

1. Björck V, Påhlman LI, Bodelsson M, Petersson AC, Kander T. Morbidity and mortality in critically ill patients with invasive group A streptococcus infection: an observational study. Crit Care. 2020. https://doi.org/10.1186/ s13054-020-03008-z.

2. Parks $T$, Barrett $L$, Jones N. Invasive streptococcal disease: a review for clinicians. Br Med Bull. 2015;115:77-89.

3. Ustin JS, Malangoni MA. Necrotizing soft-tissue infections. Crit Care Med. 2011;39:2156-62.

4. Waddington $\mathrm{CS}$, Snelling TL, Carapetis JR. Management of invasive group A streptococcal infections. J Infect. 2014;69(Suppl1):S63-9.

\section{Publisher's Note}

Springer Nature remains neutral with regard to jurisdictional claims in published maps and institutional affiliations. 